most important response is to offer a sound base of support for combating emerging diseases where they start, relying less on the rapid influx of international experts and the long-distance shipping of specimens and more on "home grown" talent, equipped with the tools and training that they need. Achieving these goals will be difficult. Beyond supplying medicine and laboratory equipment, tackling the problem will require addressing such complex issues as low salaries and "brain drain," civil unrest, corruption, and human rights. Dr. Conteh was exceptional because he persisted in the face of these challenges, but we cannot routinely depend on such heroes. Governments in developing countries, with international support, need to build the base to create stable job and training opportunities, adequate physical infrastructure, and safe working environments to foster the development of local expertise and encourage local physicians and scientists to help fill the role vacated by Dr. Conteh. Ultimately, containing emerging diseases depends on the Aniru Contehs of the world. The more support we provide to people on the front lines, the healthier and safer we all will be.

Aniru Conteh is survived by his wife, Sarah, three sons, and two daughters.

\section{Acknowledgments}

We thank Simon Mardel for his perspectives on this article.

\section{Daniel G. Bausch,* Sanie S.S. Sesay, $\dagger$ and Babafemi Oshin $\ddagger$}

*Tulane School of Public Health and Tropical Medicine, New Orleans, Louisiana, USA; †Kenema Government Hospital, Kenema, Sierra Leone; and ¥Merlin Sierra Leone, Freetown, Sierra Leone

\section{References}

1. Frame JD, Baldwin JM Jr, Gocke DJ, Troup JM. Lassa fever, a new virus disease of man from West Africa. I. Clinical description and pathological findings. Am J Trop Med Hyg. 1970;19:670-6.

2. Troup JM, White HA, Fom AL, Carey DE. An outbreak of Lassa fever on the Jos plateau, Nigeria, in January-February 1970. A preliminary report. Am J Trop Med Hyg. 1970;19:695-6.

3. Buckley SM, Casals J. Lassa fever, a new virus disease of man from West Africa. 3. Isolation and characterization of the virus. Am J Trop Med Hyg. 1970;19:680-91.

4. White HA. Lassa fever. A study of 23 hospital cases. Trans R Soc Trop Med Hyg. 1972;66:390-401.

5. Fraser DW, Campbell CC, Monath TP, Goff PA, Gregg MB. Lassa fever in the Eastern Province of Sierra Leone, 1970-1972. I. Epidemiologic studies. Am J Trop Med Hyg. 1974;23:1131-9.

6. Monath TP, Maher M, Casals J, Kissling RE, Cacciapuoti A. Lassa fever in the Eastern Province of Sierra Leone, 19701972. II. Clinical observations and virolog- ical studies on selected hospital cases. Am J Trop Med Hyg. 1974;23:1140-9.

7. McCormick JB, Webb PA, Krebs JW, Johnson KM, Smith ES. A prospective study of the epidemiology and ecology of Lassa fever. J Infect Dis. 1987;155:437-44.

8. Bausch DG, Rollin PE, Demby AH, Coulibaly M, Kanu J, Conteh AS, et al. Diagnosis and clinical virology of Lassa fever as evaluated by enzyme-linked immunosorbent assay, indirect fluorescentantibody test, and virus isolation. J Clin Microbiol. 2000;38:2670-7.

9. Monath TP, Mertens PE, Patton R, Moser CR, Baum JJ, Pinneo L, et al. A hospital epidemic of Lassa fever in Zorzor, Liberia, March-April 1972. Am J Trop Med Hyg. 1973;22:773-9.

10. Bloch A. A serological survey of Lassa fever in Liberia. Bull World Health Organ. 1978;56:811-3.

11. Bausch DG, Demby AH, Coulibaly M, Kanu J, Goba A, Bah A, et al. Lassa fever in Guinea: I. Epidemiology of human disease and clinical observations. Vector Borne Zoonotic Diseases. 2001;1:269-81.

12. Lukashevich LS, Clegg JC, Sidibe K. Lassa virus activity in Guinea: distribution of human antiviral antibody defined using enzyme-linked immunosorbent assay with recombinant antigen. J Med Virol. 1993;40:210-7.

13. Saluzzo JF, Adam F, McCormick JB, Digoutte JP. Lassa fever virus in Senegal. J Infect Dis. 1988 Mar;157:605.

Address for correspondence: Daniel G. Bausch, Tulane School of Public Health and Tropical Medicine, Department of Tropical Medicine, SL-17, 1430 Tulane Ave., New Orleans, LA 70112, USA; fax: 504-988-6686; email: dbausch@tulane.edu

\title{
Correction, vol. 10, no. 9
}

In "SARS-CoV Antibody Prevalence in All Hong Kong Patient Contacts" by Gabriel M. Leung et al., errors occurred on p. 1654. The seventh sentence read "those who declined testing" but should have been "those who consented to testing."

The corrected sentence reads as follows: However, those who consented to testing were more likely to report more frequent contact and closer relationships with SARS patients, more febrile or respiratory illness episodes since February, and a travel history to SARS-affected regions, which may have biased our seroprevalence estimate upwards.

The corrected article appears online at http://www.cdc. gov/ncidod/EID/vol10no9/02-0155.htm

We regret any confusion these errors may have caused.

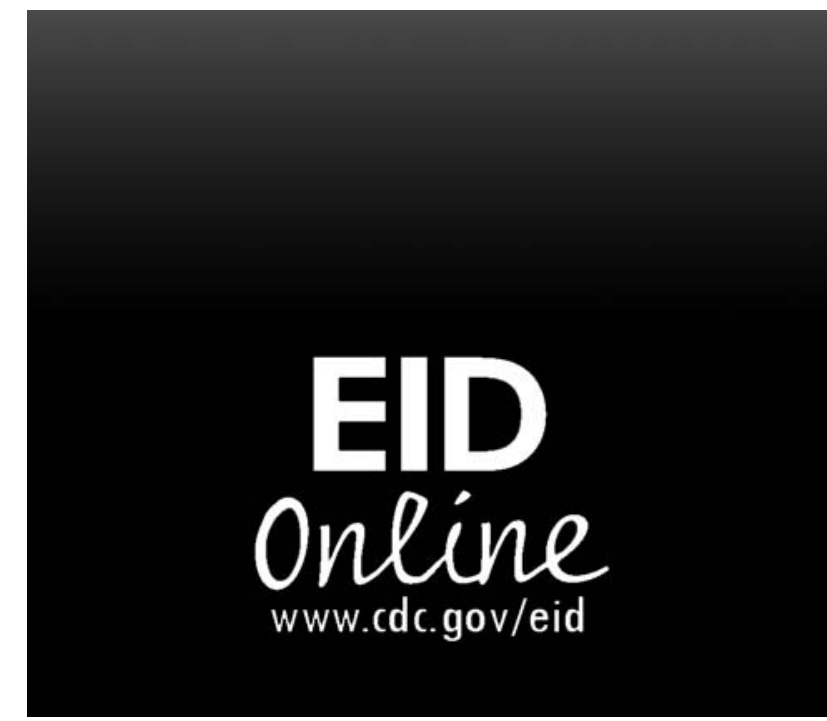

